\title{
Institute of Substitution of Punishment and Other Measures in Criminal Law of Russian Federation and Foreign Countries
}

\author{
Svetlana Zakharova \\ Department of Criminal Law \\ Academy of Law and Management of \\ the Federal Penal Service of Russia \\ Ryazan, Russian Federation \\ svetlanaza@yandex.ru \\ Lyudmila Budanova \\ Department of Organization of the \\ Regime and Detective Activities in the \\ Penitentiary System \\ Pskov branch of the Academy of Law \\ and Management of the Federal Penal \\ Service of Russia \\ Pskov, Russian Federation \\ milabudanovapskov@mail.ru
}

\author{
Sergey Rihanov \\ Monitoring and Support Team quality \\ training \\ Academy of Law and Management of \\ the Federal Penal Service of Russia \\ Ryazan, Russian Federation \\ sergey.rianov@mail.ru \\ Ulyana Gromova \\ Pskov State University \\ Pskov, Russian Federation \\ marina-andreeva.2011@yandex.ru
}

\author{
Andrei Shcherbakov \\ Department of Organization of the \\ Regime and Detective Activities in the \\ Penitentiary System \\ Pskov branch of the Academy of Law \\ and Management of the Federal Penal \\ Service of Russia \\ Pskov, Russian Federation \\ andrey-sherbakov-1973@yandex.ru
}

\begin{abstract}
- the article discusses the issues of regulating the replacement of criminal punishments and other measures of a criminal law nature under the laws of the Russian Federation and foreign countries to clarify the grounds and conditions for its application in relation to convicts of fines, compulsory labor, correctional labor, detention in a disciplinary military unit, restriction freedom, forced labor, imprisonment for a fixed term and others. As a result of the study, we came to the conclusion that it is necessary to expand the list of punishments for which it is possible to use the replacement of the unserved part of the sentence with a milder punishment, and the feasibility of using a multi-stage penalty replacement system as the main form of punishment imposed by the court in connection with malicious evasion of his serving, taking into account the current system of criminal penalties, and in some cases on the admissibility of a direct replacement of the fine with imprisonment, it is advisable to apply have a provision on fine days. The provisions of a written reminder to the fined person of the time of its final payment may be borrowed in Russian criminal law. Of interest is the provision on increasing the amount of the fine in case of delayed payment.
\end{abstract}

Keywords - replacement of criminal punishment and measures of a criminal law; fine; forced labor; imprisonment; grounds and conditions for the replacement of punishment by the law of foreign countries.

\section{INTRODUCTION}

Forensic scientists pay close attention to the issues of replacing the unserved part of the sentence with a milder type of punishment, as well as the problems of replacing the sentences imposed by the court in case of malicious evasion from serving them with more severe punishments. T.G. Chernenko, I.V. Masalitin noted that replacing the unserved part of the sentence with a milder type of punishment is seen as encouraging convicts who are positively characterized during the serving of sentences, and is aimed at stimulating the positive behavior of convicts during the period of serving their sentences [1, p. 122-132]. At the same time V.M.
Stepashin considers the problems of the mandatory replacement of punishments not related to deprivation of liberty with stricter measures of state coercion as a result of malicious evasion from serving the applicable sentences, and also raises the question of the permissibility of multi-stage substitution of punishments [2, p. 90-96]. Certain issues of regulating the replacement of criminal sentences both in the direction of improving the provisions of the convict, and in the direction of deteriorating his situation under the criminal law of Russia and foreign countries, currently need a systematic review.

\section{METHODS}

A comparative legal analysis of the norms of the Criminal Code of the Russian Federation and the Criminal Codes of foreign countries (Federal Republic of Germany, Switzerland) was carried out, during which a multi-stage substitution of sentences under Russian law was established as to improve the situation of the convicted person, and towards the deterioration of his legal status during the period of serving his sentence.

\section{RESULTS}

As a result of the study, we came to the conclusion that it is necessary to expand the list of punishments for which it is possible to use the replacement of the unserved part of the sentence with a milder punishment, and the feasibility of using a multi-stage penalty replacement system as the main form of punishment imposed by the court in connection with malicious evasion of his serving, taking into account the current system of criminal penalties, and in some cases on the admissibility of a direct replacement of the fine with imprisonment, it is advisable to apply have a provision on fine days. The provisions of a written reminder to the fined person of the time of its final payment may be borrowed in Russian criminal law. Of interest is the provision on 
increasing the amount of the fine in case of delayed payment.

\section{DISCUSSION}

In the theory of criminal law, there are many reasons for the classification of substitution of punishment. So, in the decision-making phase of replacing one type of punishment with another or criminal law measures, it is classified into two types: firstly, the replacement at the stage of sentencing and sentencing or another criminal measure [3, p. 76].

In terms of the nature of the legal consequences for a convicted person in the Criminal Code of the Russian Federation, the replacement of criminal sentences in their execution, on the one hand, acts as a sub-institution of exemption from serving a sentence when replacing an unserved part of a sentence with a milder type of punishment, and on the other hand, as a form of responsibility for malicious evasion of serving the sentence imposed by the court, expressed in the replacement of a more severe type of punishment.

It should be emphasized that replacing the unserved part of the sentence with a milder type of punishment is not allowed in all cases, but only if the convicted person is serving in a disciplinary military unit, forced labor or imprisonment (part 1 of article 80 of the Criminal Code of the Russian Federation).

It must be borne in mind that by replacing the unserved part of the sentence with a milder type of punishment from the general list of punishments, the court must choose the most appropriate legal restrictions and prohibitions established by law [4].

The initially imposed punishment in the form of imprisonment at the stage of sentencing is replaced by punishments in the form of detention in a disciplinary military unit against convicted servicemen, or by forced labor. In the process of execution of the punishment in the form of detention in a disciplinary military unit and forced labor, if the conditions established by the legislator are met, the unserved part of the specified types of punishments may be replaced by the court with a milder type of punishment.

The Criminal Code does not provide for the possibility of replacing the fine imposed as an additional punishment. $\mathrm{N}$. V. Olkhovik notes that in case of malicious evasion from paying it, the collection of a fine should be carried out in a forced manner. However, practice shows that in the absence of the possibility of enforcing a fine, the debtor is actually released from the execution of the criminal punishment assigned to him [5, p. 17].

In all of the cases, the legislator speaks of evading or maliciously avoiding serving a certain type of punishment, as well as recognizing the convicted person as a malicious violator of the order and conditions of serving forced labor. To understand the content of these categories, it is necessary to refer to the penal legislation, which, in our opinion, is not entirely justified. A. S. Kolosov notes that "... the concept of malicious evasion of a fine is a criminal law category ..., it should be placed in part 5 of art. 46 of the Criminal Code ... "[6, p. 140].

A. S. Kolosov notes that the criminal law of foreign countries has elaborated on the issue of responsibility for evading serving sentences that are not related to deprivation of liberty, while its main form is the replacement of punishment, from which the convict evades serving, deprivation of liberty [6, p. 114].

K. E. Lukovkin, considering the foreign model of the execution of a criminal sentence in the form of a fine, noted that as one of the supporting parameters of the analysis, it is advisable to monitor the indicators of substitution of punishment with more or less severe penalties and incentives. He emphasized that the fine is one of the main types of punishments and is used for misconduct - an unlawful act of lesser danger than a crime. A monetary fine can only be replaced with more severe penalties $[7$, p. 335336].

V. M. Stepashin noted that the substitute punishment should be compared with the content of the punishment, from which the convicted person evaded serving. In his opinion, the substitute punishment should imply a more substantial range of restrictions and deprivations of certain rights of the convicted person, as well as the particularities of the procedure for the execution of the substitute punishment should provide guarantees for the implementation of the new measure [8, p. 185].

In $\S 43$ of the Criminal Code of Germany provides for the possibility of replacing a fine with imprisonment. So, instead of the unpaid fine, unlike the legislation of the Russian Federation, imprisonment is applied [9, p. 139146]. It should be noted that there is a multi-stage system of substitution of sentences, which causes scientific discussion in Russian Federation.

The multi-stage change of sentences was allowed by S. F. Milyukov and O. V. Starkov, who noted that "as a result of the aforementioned replacement, the person sentenced to a fine ... may end up in custody ... as a result of the subsequent replacement of correctional labor with imprisonment" [10, p. 70]. In contrast, B. Karganova denies the possibility of multi-stage substitution of sentences, referring to the legislative provision that it applies to persons sentenced to correctional labor. If the fine is replaced as the main type of punishment by correctional labor, they are applied according to the judge's order to replace the more severe type of punishment for malicious evasion of serving the fine [11, p. 33]. Filimonov is of the opinion that the current Criminal Code of the Russian Federation does not answer the question of whether the punishments imposed for malicious evasion, in turn, can be replaced on the same basis with other more severe punishments [12, p. 607]. A worthy way out of this situation was formulated by V. M. Stepashin, who proposed replacing Part 5 of Art. 46 and h. 5 Article 53 of the Criminal Code of the Russian Federation, the word "appointed" to the word "applied" [2, p. 94].

Along with the implementation of this proposal, in our opinion, a provision should be borrowed on the possibility of directly replacing the unpaid fine with imprisonment. To do this, in the criminal legislation of Russia it is advisable to apply the provision on daily rates in determining the fine, as provided for by the laws of Germany.

In accordance with $\S 40$ of the Criminal Code of Germany, a fine is imposed in daily rates. When replacing an unpaid fine with a deprivation of liberty, the courts take into account that one day rate corresponds to one day of imprisonment, and the minimum term of imprisonment is one day [9, p. 139-146]. 
N. F. Kuznetsova and L. Wenzel, examining the criminal law of Germany, noted that the basis for applying the replacement of a monetary fine with deprivation of liberty is the failure to pay the fine specified in the court verdict within the prescribed time [13, p. 120]. We generally agree with this conclusion. But it should be noted in this case that the fine is not paid without good reason when there is a real possibility of paying it.

Thus, article 49 of the Criminal Code of Switzerland establishes a provision according to which, if the convicted person fails to pay a fine within the time period set for him and otherwise does not work him out, the competent authority will charge the debt if any result can be expected from this (Part 2 of Article 49 of the Criminal Code of Switzerland).

If the convicted person does not pay the fine at all and otherwise does not work it out, then the judge replaces the fine with arrest (para. 1 part 3 of article 49 of the Criminal Code of Switzerland). Swiss lawmaker notes that nonpayment should be due to the lack of a good reason. If the convicted person proves to the judge that, without fault, he is in a state where he cannot pay the fine, then the judge can cancel the replacement of the fine.

In the case of substitution of a fine by arrest, thirty francs of the fine shall be equal to one day of arrest, and the commuted sentence shall not exceed a period of three months. Provisions for the conditional application of punishment apply to commuted punishment $[15$, p. $110-$ 111].

\section{CONCLUSIONS}

A study of the institution of the replacement of criminal punishments and other measures of a criminal law nature under the Russian legislation and the criminal law of certain foreign states allowed us to formulate the following conclusions:

1) the replacement of criminal punishment under the laws of foreign countries is not allocated to an independent criminal law institution, as provided for by the criminal legislation of the Russian Federation;

2) the legislation of foreign states does not regulate the issues of replacing the unserved portion of punishment in the process of its execution with milder types of punishment;

3 ) it is necessary to expand the list of punishments, when serving which it is possible to replace the unserved part of the punishment with a milder type of punishment;

4) it is necessary to legislatively consolidate a multi-stage system of substitution of punishments in case of evasion from serving substitute punishments;

5) the provisions on a written reminder to the fined person of the time of its final payment may be borrowed in the Russian criminal law;
6) it is advisable to consider increasing the amount of the fine in case of delayed payment.

\section{REFERENCES}

[1] Chernenko T.G., Masalitina I.V. Some problematic issues of replacing criminal punishment with a milder type of punishment // Tomsk State University Bulletin. Right. 2019. № 12. pp. 122-132. DOI: 10.17223 / 22253513/32/10.

[2] Stepashin V.M. The problem of the mandatory replacement of punishment more stringent / V.M. Stepashin // Law Enforcement Review. 2018. vol. 2, no. 2, pp. 90-96. DOI: 10.24147 / 25421514.2018. 2 (2). 90-96

[3] Zakharova S.S., Rianov S.A. The concept and types of substitution of punishment in the criminal law of the Russian Federation // Differentiation and individualization of responsibility in criminal and criminal executive law: proceedings of the Intern. scientific-practical Conf., dedicated to the 75th anniversary of L.L. Kruglikova (January 11, 2015) / Ed. V.F. Lapshin. Ryazan: Academy of the Federal Penitentiary Service of Russia, 2015. pp. 71-77.

[4] Brovkina, A., Vezlomtsev, V., Zakharova, S., Shuranova, O., Truntsevsky, Y. System of criminal penalties of Russian federation: Legal regulation and sentencing practice. (2019) E3S Web of Conferences, 135, article № 04066. DOI: 10.1051 / e3sconf / 201913504066.

[5] Olkhovik N.V. Substitution of a criminal penalty: a myth or reality? / N.V. Olkhovik // Criminal justice. 2015. No. 1 (5). pp. 16-19.

[6] Kolosov A.S. Responsibility for evading serving sentences that are not related to isolation of the convicted person from society: dis. ... cand. legal sciences. M., 2005.

[7] Lukovkin K.E. Foreign model of the execution of criminal punishment in the form of a fine on the example of the countries of the continental system of law // Criminal Executive Law. 2018.Vol. 13 (1-4). № 3. pp. 334-338.

[8] Stepashin V.M. Replacing punishment / V.M. Stepashin // Law Enforcement Review. 2017. vol. 1, no. 2, pp. 184-190. DOI: 10.24147 / 2542-1514.2017. 12). 184-190.

[9] The Criminal Code of the Federal Republic of Germany / Scientific. ed. and entry. article doct. legal Sciences, Professor D.A. Shestakova, foreword by G.-G. Yesheka; translation from German N.S. Crustacean. St. Petersburg: Publishing House «Legal Center Press», 2003.

[10] Starkov O.V. Punishment: criminal law and criminopenological analysis / O.V. Starkov, S.F. Milyukov. St. Petersburg: Legal Center Press, 2001. 461 p.

[11] Karganova B. The place of a fine in the punishment system under the Criminal Code of the Russian Federation / B. Karganova // Criminal law. 2003. No. 4. pp. 33-35.

[12] Filimonov V.D. The legal nature of malicious evasion from serving a sentence / V.D. Filimonov // Correlation of crimes and other offenses: modern problems: materials IV International. scientific-practical Conf. The 250th anniversary of the founding of Moscow. state University of them. M.V. Lomonosov (legal faculty. Moscow State University named after MV Lomonosov, May 27-28, 2004). M .: LexEst, 2005. pp. 606-609.

[13] Kuznetsova NF, Wenzel L. Criminal law of Germany. M.: Publishing House of Moscow State University, 1980.

[14] Swiss Penal Code / Scientific Editing, Foreword and Translation from German Cand. legal sciences A.V. Serebrennikova .. St. Petersburg: Publishing House «Legal Center Press», 2002. 